\title{
Concentraciones de LH en periodos de transición reproductiva en cabras criollas $x$ Nubia con diferente condición nutricional
}

\section{Serum LH concentrations during seasonal reproductive transitions in criollo $x$ Nubian goats with different nutritional status}

\author{
Eliab Estrada-Cortésaf, Jorge Urrutia-Moralesc, Eugenio Villagómez-Amezcuadf, Mario A.

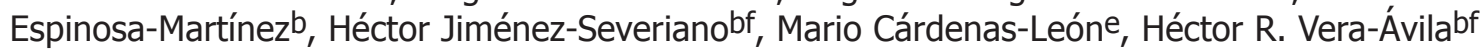

\begin{abstract}
RESUMEN
Se determinó el efecto de las reservas corporales de energía (IMC) y el consumo diario de alimento (CA), sobre la LH sérica durante las transiciones hacia época anovulatoria (TA) y reproductiva (TR). Doce cabras Criollas/ Nubia, ovariectomizadas con implantes s.c. de 17- $\beta$ estradiol, se dividieron en dos grupos $(n=6)$, uno de IMC alto (IMCA) y otro bajo (IMCB). Dentro de grupo de IMC se establecieron dos subgrupos $(n=3) ;$ con restricción de alimento (CRCA) y sin restricción temporal (SRCA). Se determinó la frecuencia de pulsos (FPLH), concentración media (CMLH) y basal de LH (CBLH). Durante TA se observó disminución gradual de FPLH, CMLH y CBLH (2.08, 1.41, 0.41 pulsos/6 h; 2.1, 1.21, $0.51 \mathrm{ng} / \mathrm{ml} ; 1.3,0.8,0.4 \mathrm{ng} / \mathrm{ml} ; P<0.01)$. En TR aumentaron CMLH y CBLH (1.01, 1.58, 1.87 $\mathrm{ng} /$ $\mathrm{ml} ; 0.57,0.98,1.04 \mathrm{ng} / \mathrm{ml} ; P<0.01)$. Cabras con IMCA presentaron mayor FPLH que las de IMCB durante TA (2.05 vs 0.55 pulsos $/ 6 \mathrm{~h} ; \mathrm{P}<0.05)$ y TR (3.2 vs 0.9 pulsos $/ 6 \mathrm{~h} ; \mathrm{P}<0.01)$ y mayor CMLH durante TR (2.1 vs $0.87 \mathrm{ng} / \mathrm{ml}$; $P<0.01)$. Durante TA, la restricción en CA provocó disminución más temprana de CMLH y CBLH en cabras con IMCA $(P<0.05)$, haciéndolas similares a cabras con IMCB. Independientemente del IMC, durante TR la restricción en CA disminuyó FPLH y CBLH $(P<0.05)$. En cabras criollas cruzadas, la secreción de LH es modulada por el IMC y el CA durante los periodos de transición reproductiva. A su vez durante TA, la restricción temporal en CA puede disminuir la secreción de LH aún en cabras con IMC alto.
\end{abstract}

PALABRAS CLAVE: Nutrición, Estacionalidad reproductiva, Cabra.

\begin{abstract}
The effect of body energy reserves (BMI) and daily feed intake (FI), on serum LH during transitions into the anovulatory (AT) or breeding season (BT) was determined. Twelve ovariectomized Criollo/Nubian goats, bearing s.c. 17- $\beta$ estradiol implants, were assigned to two groups of BMI $(n=6)$ : high (HBMI) and low BMI (LBMI). Within each BMI group, two subgroups $(n=3)$ were established: with (WFIR) and without (WOFIR) temporal restriction in FI. LH pulse frequency (LHF) and mean (LHM) and basal (LHB) serum LH concentrations were determined. LHF, LHM and LHB gradually diminished during AT $(2.08,1.41,0.41$ pulses/6 h; 2.1, 1.21, $0.51 \mathrm{ng} / \mathrm{ml} ; 1.3,0.8,0.4 \mathrm{ng} /$ $\mathrm{ml} ; P<0.01)$, whereas LHM and LHB gradually increased during BT $(1.01,1.58,1.87 \mathrm{ng} / \mathrm{ml} ; 0.57,0.98,1.04 \mathrm{ng} /$ $\mathrm{ml} ; P<0.01)$. HBMI goats had greater LHF than LBMI goats during AT (2.05 vs 0.55 pulses/6 $h ; P<0.05)$ and $B T$ (3.2 vs 0.9 pulses $/ 6 \mathrm{~h} ; P<0.05)$, and also greater LHM during BT $(2.1$ vs $0.87 \mathrm{ng} / \mathrm{ml} ; P<0.01)$. During AT, temporal feed restriction caused an earlier decrease on LHM and LHB in HBMI goats making their profile similar with LBMI goat's profile. During BT, temporal feed restriction diminished LHF and LHB independently of BMI (2.8 vs 1.3 pulses/ $6 \mathrm{~h}$ and 1.18 vs $0.55 \mathrm{ng} / \mathrm{ml}$ for WOFIR vs WFIR; $P<0.05$ ). Body energy reserves and daily feed intake modulate LH secretion during reproductive transitions in Criollo/Nubian goats. Moreover, temporal restriction in feed intake might diminish LH secretion during transition into the anovulatory season, even in goats with high BMI.
\end{abstract}

KEY WORDS: Nutrition, Reproductive seasonality, Female goat.

\footnotetext{
Recibido el 17 de junio de 2014. Aceptado el 8 de septiembre de 2014.

a Campo Experimental Centro Altos de Jalisco - INIFAP. México.

b Centro Nacional de Investigación Disciplinaria en Fisiología y Mejoramiento Animal - INIFAP. Plaza Santa Teresita 111, Col. Plazas del Sol, 76090, Querétaro, Qro. México; Tel/Fax 52-419-2920036 Ext 129; vera.hector@inifap.gob.mx. Correspondencia al último autor.

Campo Experimental San Luis - INIFAP. México.

Centro Nacional de Investigación Disciplinaria en Microbiología - INIFAP. México.

Departamento de Biología de la Reproducción - INCMNSZ. México.

Facultad de Estudios Superiores Cuautitlán - UNAM. México.
} 


\section{INTRODUCCIÓN}

Existen evidencias de que la duración de la época de anestro/anovulatoria puede estar influenciada por el plano nutricional y la condición corporal en genotipos caprinos considerados de estacionalidad moderada( 1,2$)$. Asimismo, se ha observado que independientemente de la condición corporal, restricciones temporales en el consumo de alimento pueden alargar la duración del periodo anovulatorio en cabras criollas cruzadas, resaltando el efecto regulador de este componente(3).

En los mamíferos con estacionalidad reproductiva, el inicio y fin del periodo de anestro/anovulación estacional está determinado por la disminución e incremento en la frecuencia de secreción pulsátil de GnRH y por consiguiente de $\mathrm{LH}^{(4)}$, lo cual se refleja en las concentraciones séricas de esta última(5). Esto, derivado fundamentalmente de un aumento y disminución en la sensibilidad del hipotálamo a la retroalimentación negativa ejercida por los estrógenos(6). Asimismo, el estrés nutricional también puede ocasionar un aumento en la sensibilidad del hipotálamo a la retroalimentación negativa de los estrógenos en rumiantes domésticos, lo cual afecta negativamente la secreción pulsátil de $\mathrm{GnRH} / \mathrm{LH}$ y consecuentemente, la actividad cíclica ovulatoria $(7,8)$. Se considera que en estos animales el mediador del efecto de retroalimentación negativa de los estrógenos sobre la secreción de $\mathrm{GnRH} / \mathrm{LH}$, es un grupo neuronal localizado en la región mediobasal del hipotálamo que utiliza a las Kisspeptinas, Neurocinina B y Dinorfina como neuromediadores (neuronas KNDy) ${ }^{(9)}$. De acuerdo a lo anterior, es posible que en rumiantes domésticos estacionales, las neuronas KNDy actúen como integradoras de las señales fotoperiódicas y nutricionales para determinar la duración del periodo anovulatorio. No obstante, señales nutricionales con efectos a nivel ovárico también podrían estar implicadas(10).

\section{INTRODUCTION}

Duration of the anestrus/anovulatory season may be influenced by the nutritional level and body condition in goat genotypes of moderate seasonality $(1,2)$. Furthermore, regardless the body condition, temporary restrictions on feed intake can extend the duration of the anovulatory period in Creole crossbred goats, highlighting the regulating effect of this component(3).

In mammals with reproductive seasonality, the start and end of the seasonal anestrus/ anovulation period is determined, respectively, by the decrease and increase in the frequency of pulsatile secretion of $\mathrm{GnRH}$ and $\mathrm{LH}(4)$, which is reflected in the serum concentrations of $\mathrm{LH}(5)$. This is mainly derived from a hypothalamic increase and decrease in sensitivity to the negative feedback exerted by estrogens $(6)$. Nutritional stress can also cause an increase in the hypothalamic sensitivity to the negative feedback of estrogens in domestic ruminants, event which in turn negatively affects the pulsatile $\mathrm{GnRH} / \mathrm{LH}$ secretion and consequently the cyclic ovulatory activity $(7,8)$. A neuronal group located in the mediobasal hypothalamus, that uses the Kisspeptines, Neurokinin B and Dynorphin as neurotransmitters (KNDy neurons), is considered to be the mediator of the negative feedback effect of estrogens on the $\mathrm{GnRH} / \mathrm{LH}$ secretion in domestic ruminants( $(9)$. In this way, it is possible that in seasonal domestic ruminants, KNDy neurons act as integrators of photo periodical and nutritional signals to determine the duration of the anovulatory period. However, direct nutritional effects at the ovarian level may also be involved(10).

As in other mammals, the nutritional status is an important regulator of reproductive function in ruminants, particularly the energy component(7). In this regard, it has been established that the energy status of an animal involves the body energy reserves and their mobilization, along with the incoming energy 
Al igual que en otras especies de mamíferos, la condición nutricional es un regulador importante de la función reproductiva en rumiantes, particularmente en lo que se refiere al componente energético(7). En ese sentido, se ha establecido que el estado energético de un animal involucra a las reservas corporales de energía y a su movilización a partir de éstas, junto con el ingreso de energía asociado al consumo diario de alimento. Cada uno de estos componentes genera señales metabólicas que de manera interactiva o independiente pueden regular la secreción de GnRH/LH(11-14).

El presente estudio se diseñó para determinar el efecto de las reservas corporales de energía y el consumo diario de alimento, sobre las concentraciones séricas de LH durante los periodos de transición reproductiva en un genotipo caprino considerado como de estacionalidad moderada. La hipótesis experimental fue que durante los periodos de transición reproductiva estacional, el consumo diario de alimento juega un papel más importante en la regulación de secreción de LH que las reservas corporales de energía, de forma similar a lo observado con la actividad ovulatoria en un estudio realizado de manera paralela(3).

\section{MATERIALES Y MÉTODOS}

El estudio se llevó a cabo entre febrero y octubre de 2005, en el estado de San Luís Potosí, México (220 14' 03" N, $100^{\circ} 53^{\prime} 11^{\prime \prime}$ O y $1,835 \mathrm{msnm}$ ). El fotoperiodo en esta zona varía de 13 h 22 min en el solsticio de verano a $10 \mathrm{~h} 38 \mathrm{~min}$ en el de invierno. El clima se clasifica como seco con una precipitación anual promedio de $285.9 \mathrm{~mm}$, concentrada entre junio a septiembre. Las variaciones de fotoperiodo, temperatura media y precipitación pluvial ocurridas durante el periodo experimental se muestran en la Figura 1.

Se utilizaron 12 cabras adultas de raza criolla encastadas de Nubia, sin gestar ni lactar, aisladas del contacto con machos cabríos y bajo associated with daily feed intake. Each of these components generate metabolic signals that can regulate $\mathrm{GnRH} / \mathrm{LH}$ secretion by an interactive or independent way(11-14).

The present study was designed to determine the effect of body energy reserves (BMI) and daily feed intake, on serum LH concentrations during the reproductive transition periods in a goat genotype considered as moderate seasonal breeder. The experimental hypothesis was that during periods of seasonal reproductive transition, daily feed intake plays a more important role in the regulation of LH secretion that the body energy reserves, similar to what was observed with the ovulatory activity in a study conducted in parallel(3).

\section{MATERIALS AND METHODS}

The study was conducted between February and October 2005, in the State of San Luis Potosi, Mexico (22。 14' 03" N, $100^{\circ} 53^{\prime}$ '11" W and $1,835 \mathrm{~m}$ asl). Photoperiod in this area varies from $13 \mathrm{~h} 22 \mathrm{~min}$ in the summer solstice to 10 h $38 \mathrm{~min}$ in the winter one. The climate is classified as dry with an average annual rainfall of $285.9 \mathrm{~mm}$, concentrated between June and September. The photoperiod, temperature and rainfall variations that occurred during the experimental period are shown in Figure 1.

Twelve (12) adult Criollo/Nubian goats not pregnant and nor lactating, isolated from bucks contact and under natural photoperiod were used. All experimental procedures were performed according to the international guide of principles for biomedical research in animals(15).

\section{Management}

Six weeks prior to the start of the study all goats were ovariectomized and implanted with subcutaneous silastic tubes (12 $\mathrm{mm}$ in length, $1.83 \mathrm{~mm}$ and $1.32 \mathrm{~mm}$ of outer and inner diameters, respectively; Dow Corning, Midland, MI, USA), packed with a $10 \mathrm{~mm}$ column of 
fotoperiodo natural. Todos los procedimientos experimentales se realizaron de acuerdo a la guía internacional de principios para investigación biomédica en animales(15).

\section{Manejo}

Seis semanas previas al inicio del estudio todas las cabras fueron ovariectomizadas y se les insertó un implante subcutáneo de Silastic (12 $\mathrm{mm}$ de longitud, $1.83 \mathrm{~mm}$ y $1.32 \mathrm{~mm}$ de diámetros externo e interno, respectivamente; Dow Corning, Midland, MI, USA), con 17- $\beta$ estradiol (Sigma Chemical Compañy, St Louis, MO, USA), empacado en $10 \mathrm{~mm}$ de longitud del tubo. Antes de su inserción, los implantes se incubaron en solución salina fisiológica por tres días a $37^{\circ} \mathrm{C}$ para evitar un pico de liberación inicial. La concentración sérica promedio de estradiol en los animales después de ser implantados fue de $1.25 \pm 0.8 \mathrm{pg} / \mathrm{ml}$ (Coat- a -Count, Siemens Medical Solutions Diagnostics), similar a las concentraciones basales de estradiol observadas en cabras con actividad cíclica ovulatoria(16). La sensibilidad del ensayo fue de $0.29 \mathrm{pg} / \mathrm{ml}$ y los coeficientes de variación intra e inter ensayo fueron 8.2 y $7.9 \%$, respectivamente.

Tres meses previos al inicio del experimento se manipuló la dieta para conformar dos grupos: 1) índice de masa corporal (IMC) alto (IMCA, $\mathrm{n}=6$; IMC $\geq 10.5$ ); y 2) IMC bajo (IMCB, $\mathrm{n}=6$; IMC $\leq 10.0)$. El IMC se considera un buen estimador de las reservas corporales de energía en hembras caprinas(17) y se calcula de acuerdo a una fórmula establecida(15).

Una vez conformados los grupos de IMC, la alimentación de los animales se basó en una sola dieta (9.76 \% de PC y 2.02 Mcal de EM/ $\mathrm{kg}$ de alimento en base seca), ajustando la ración de acuerdo al peso vivo individual para lograr niveles nutricionales de mantenimiento(18) y estabilizar el peso e IMC de acuerdo al grupo correspondiente. Desde el periodo previo al inicio del experimento y durante éste, las cabras permanecieron estabuladas en corrales
17- $\beta$-estradiol (Sigma Chemical Company, St Louis, MO, USA). To avoid an initial release peak, implants were incubated before insertion in physiological saline solution for $3 \mathrm{~d}$ at $37^{\circ} \mathrm{C}$. The average serum estradiol concentration in

Figura 1. Cambios de la temperatura media ambiental (a), precipitación pluvial (b) y fotoperiodo (c) durante el periodo experimental

Figure 1. Changes in mean environmental temperature (a), rainfall (b) and photoperiod (c) during the experimental period

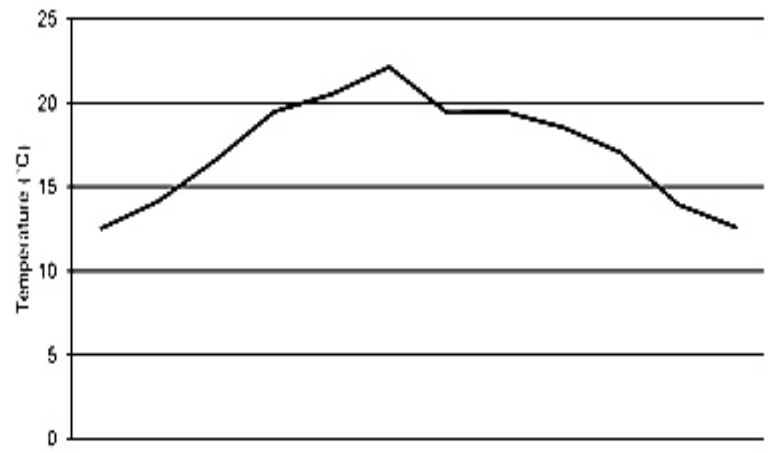

b

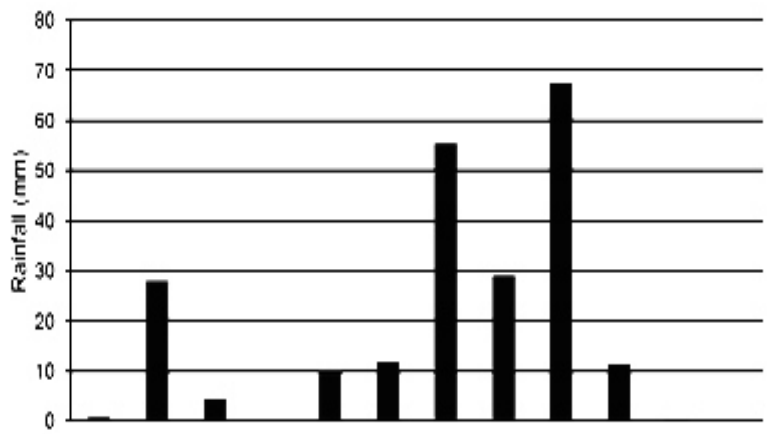

C

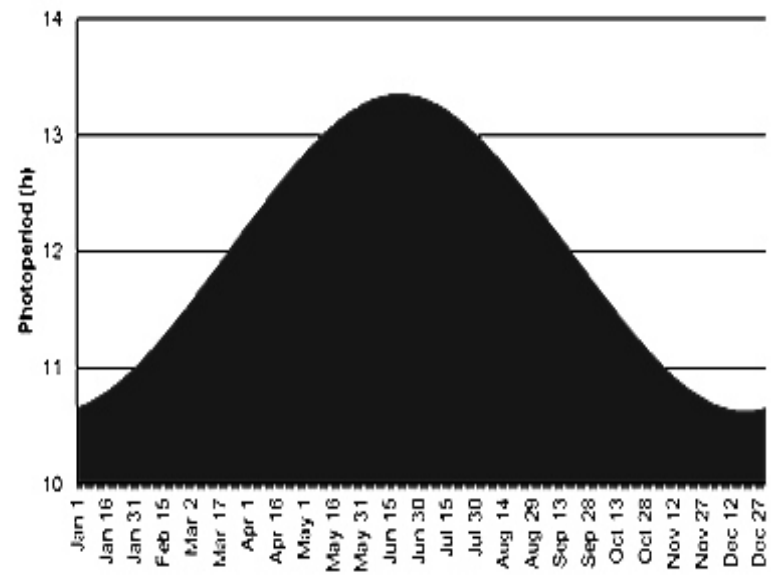


comunales con agua a libre acceso. Asimismo, se alimentaron una vez al día (0900 h) y cada una recibió su ración en comederos individuales.

Al inicio del experimento, la mitad de los animales de los grupos IMCA e IMCB se asignó de manera aleatoria a uno de dos consumos diarios de alimento (CA): 1) oferta del $100 \%$ de la ración de mantenimiento de forma constante (SRCA); 2) oferta del $100 \%$ de la ración de mantenimiento pero con restricciones temporales del $40 \%$ (CRCA). Bajo tal esquema, a los animales CRCA, se les ofreció el 100 y $60 \%$ de la ración de mantenimiento en periodos de 11 y 10 días durante todo el estudio. Lo anterior con el propósito de evitar un cambio de IMC en los animales de los subgrupos restringidos y por lo tanto, tratar de disociar el efecto de las reservas corporales de energía (IMC) y de su ingreso a través del consumo diario de alimento (CA).

\section{Muestreos}

Se realizaron tres ventanas de muestreo durante la transición hacia la época anovulatoria (muestreos 1, 2 y 3 para el 16 de febrero, 9 y 30 de marzo, respectivamente) y tres durante la transición hacia la época reproductiva (muestreos 4, 5 y 6 para el 24 agosto, 14 septiembre y 5 octubre, respectivamente). Las fechas para las ventanas de muestreo se establecieron con base a la actividad ovulatoria de un grupo de cabras intactas, de un experimento en paralelo; en éste, los días de restricción nutricional se aplicaban durante la segunda mitad del ciclo estral en curso, iniciando 10 días antes de la fecha estimada para su siguiente ovulación(3). El día previo a cada muestreo, se insertó una cánula (catéter intravenoso de poliuretano radiopaco; $18 \mathrm{G} \times$ $30 \mathrm{~cm}$, Luer Lock) en la vena yugular de las cabras; 60 min previos al muestreo (0900 h en todas las ocasiones), los animales fueron alojados en jaulas individuales y se colocaron extensiones tubulares de polietileno a las cánulas, para obtener las muestras a distancia. En cada animals after being implanted was $1.25 \pm 0.8$ $\mathrm{pg} / \mathrm{ml}$ (Coat - a - Count, Siemens Medical Solutions Diagnostics), similar to basal estradiol concentrations observed in goats with cyclic ovulatory activity(16). The sensitivity of the estradiol assay was $0.29 \mathrm{pg} / \mathrm{ml}$ and the intra and inter assay variation coefficients were 8.2 and $7.9 \%$, respectively.

Three months prior to the beginning of the experiment, the diet was manipulated to form two groups: 1) High BMI (HBMI, $\mathrm{n}=6$; $\mathrm{BMI}$ $\geq 10.5$ ); and 2) Low BMI (LBMI, $n=6$; BMI $\leq 10.0)$. BMI is considered to be a good estimator of body energy reserves in female goats(17) and is calculated according to an established formula(15).

Once the BMI groups were formed, feeding was based on a single diet $(9.76 \% \mathrm{CP}$ and $2.02 \mathrm{Mcal} \mathrm{ME} / \mathrm{kg}$ on dry basis), adjusting the ration according to the individual live weight to achieve nutritional maintenance levels(18) and stabilize the weight and BMI according to the corresponding group. From the period prior to the start of the experiment and during this, goats were stabled in communal pens with free water access. They were also fed once a day $(0900 \mathrm{~h})$ and each one received their ration in individual troughs.

At the beginning of the experiment, half of the HBMI and LBMI groups were assigned randomly to one of two daily feed intakes (FI): 1) A steadily offer of $100 \%$ of the maintenance ration without temporal restriction of $\mathrm{FI}$ (WOFIR); 2) A non-steadily offer of $100 \%$ of the maintenance ration with $40 \%$ temporary restrictions of FI (WFIR). Under such a scheme, the WFIR animals, received $100 \%$ and $60 \%$ of the maintenance ration in alternated periods of 11 and $10 \mathrm{~d}$ throughout the study. The above in order to avoid a BMI change in the subgroups of restricted animals, and therefore try to dissociate the effect of body energy reserves (BMI) from the one exerted by energy income through the daily FI. 
ventana de muestreo, se colectaron muestras de sangre cada 15 min durante 6 h; las muestras se centrifugaron a $1,400 \mathrm{xg}$ durante 15 min para la obtención de plasma sanguíneo y éste fue congelado a $-20{ }^{\circ} \mathrm{C}$ hasta la determinación de LH.

\section{Análisis hormonal}

Se cuantificó LH usando un RIA heterólogo de doble anticuerpo, validado para LH bovina(19). La hormona utilizada como referencia en la curva patrón fue la USDA-bLH-B5 (AFP-5,500) y para la marcación con I125 fue la USDA-bLHI-1 (AFP-6000); como primer anticuerpo se usó un suero de conejo anti-LH ovina (CSU-204, producido por GD Niswender). La sensibilidad del ensayo fue de $0.05 \mathrm{ng} / \mathrm{ml}$ y los coeficientes de variación intra e inter ensayo fueron 6.8 y $16.6 \%$ respectivamente. Las variables de respuesta evaluadas fueron: frecuencia de pulsos de LH (pulsos/6 h; FPLH), concentración media $(\mathrm{CMLH})$ y concentración basal de LH (CBLH). Los pulsos fueron identificados utilizando el programa Pulsar(20), el cual se calibró con los valores G siguientes: $\mathrm{G} 1=99 ; \mathrm{G} 2=2.6 ; \mathrm{G} 3=$ 1.92; $\mathrm{G} 4=1.46$; y $\mathrm{G} 5=1.13$. Se usaron cinco iteraciones, un tiempo de ajuste de valores ("smoothing time") de 180 min y se incluyeron los parámetros constante, lineal y cuadrático (SD $\left.[y]=b_{0} 6.64+b_{1}-0.12+b_{2} 0.003\right)$, estimados en función de la desviación estándar del ensayo, de acuerdo a la concentración de la hormona.

\section{Análisis estadístico}

Todos los datos se sometieron a análisis de varianza, utilizando la versión 9.0 del paquete estadístico SAS. Los valores de $P \leq 0.05$ y de $P \leq 0.10$ en cada análisis se consideraron como significativos o tendencia, respectivamente.

En ambos periodos de transición, el IMC de cada animal se consideró como variable de constatación y se analizó mediante un diseño complemente al azar en un arreglo factorial 2 $x$ 2, en donde se incluyó al IMC (IMCA e IMCB) y al CA (SRCA y CRCA) como factores. Este análisis se realizó para determinar si la

\section{Sampling}

Three sampling windows were carried out during the transition to the anovulatory season (samplings 1, 2 and 3 on February 16 and March 9 and 30, respectively) and three during the transition towards the reproductive season (samplings 4, 5 and 6 on August 24, September 24 and October 5, respectively). Sampling windows dates were established based on the ovulatory activity of a group of intact goats, observed in a parallel experiment; in this, the days of nutritional restriction were applied during the second half of the estrous cycle in progress, starting $10 \mathrm{~d}$ before the predicted date for the next ovulation(3). The day prior to each sampling, a cannula was inserted (intravenous radiopaque polyurethane catheter; $18 \mathrm{G} \times 30$ $\mathrm{cm}$, Luer Lock) in the goats jugular vein; 60 min prior to sampling (0900 $\mathrm{h}$ at all times), the animals were housed in individual cages and polyethylene tubular extensions were attached to cannulas, for getting the samples aloof. In each sampling window, blood samples were collected during $6 \mathrm{~h}$ every $15 \mathrm{~min}$ and were centrifuged at $1,400 \mathrm{xg}$ for $15 \mathrm{~min}$ to obtain blood plasma; plasma was frozen at $-20{ }^{\circ} \mathrm{C}$ until LH determination.

\section{Hormonal analysis}

LH was quantified using an heterologous double antibody RIA, validated for bovine $\mathrm{LH}(19)$. The hormone used as reference in the standard curve was the USDA-bLH-B5 (AFP-5, 500) and for I ${ }^{125}$ marking was the USDA-bLH-I-1 (AFP6000); anti-ovine-LH rabbit serum was used as the first antibody (CSU-204, produced by GD Niswender). The sensitivity of the assay was $0.05 \mathrm{ng} / \mathrm{ml}$ and intra and inter assay variation coefficients were 6.8 and $16.6 \%$ respectively. The response variables evaluated were: $\mathrm{LH}$ pulse frequency (pulses/6 h; LHF), and the mean (LHM) and basal LH concentrations (LHB). The LH pulses were identified using the PULSAR software(20), which was calibrated with the following $\mathrm{G}$ values: $\mathrm{G} 1=99 ; \mathrm{G} 2=2.6 ; \mathrm{G} 3=$ $1.92 ; \mathrm{G} 4=1.46$; and $\mathrm{G} 5=1.13$. Five iterations, and a smoothing time of 180 min were used, 
restricción temporal en el consumo de alimento afectaba o no el nivel de IMC de las cabras y con ello, corroborar si se había logrado disociar los efectos de consumo diario de alimento y reservas corporales de energía.

En ambos periodos de transición, la FPLH, CMLH y CBLH se analizaron mediante un diseño de parcelas divididas, en donde se incluyó al IMC (IMCA e IMCB) y al CA (SRCA y CRCA) como efectos de parcela grande, y al periodo de muestreo (PER; muestreos 1,2 y 3 o muestreos 4,5 y 6) como efecto de parcela pequeña en un arreglo factorial completo. Los datos de la FPLH se transformaron a raíz cuadrada de $Y+0.5$ para su análisis estadístico(21), pero en la sección de resultados se presentan los valores no transformados.

\section{RESULTADOS}

Índice de masa corporal

En ambos periodos de transición, la variable de respuesta IMC fue influenciada por el efecto de grupo de IMC $(P<0.01)$, pero no por el de CA o la interacción IMC x CA $(P>0.10)$. Los resultados indican que la condición de restricción temporal en el consumo de alimento de los and constant, linear and quadratic parameters were included (SD $[\mathrm{Y}]=\mathrm{b}_{0} 6.64+\mathrm{b}_{1}-0.12$ $+b_{2}$ 0.003); the parameters were estimated on the basis of the assay standard deviation, according to the hormone concentration.

\section{Statistical analysis}

All data were subjected to analysis of variance, using SAS 9.0 statistical software. The values of $P \leq 0.05$ and $P \leq 0.10$ in each analysis were considered as significant or trend, respectively.

In both transition periods, the BMI of each animal was considered as a verification variable and was analyzed using a completely randomized design in a $2 \times 2$ factorial arrangement, with BMI (HBMI and LBMI) and FI (WOFIR and WFIR) included as factors. This analysis was performed to determine if the temporary restriction on feed intake affected or not BMI level of goats and therefore corroborate if the effects of daily feed intake and body energy reserves had been dissociated.

In both transition periods, the LHF, LHM and LHB were analyzed using a split plot design, where the BMI (HBMI and LBMI) and FI (WOFIR and WFIR) were included as whole plot effects,

Cuadro 1. Índice de masa corporal (BMI) de las cabras por grupo de BMl y condición de consumo de alimento durante los periodos de transición reproductiva estacional ${ }^{1}$

Table 1. Goat body mass index (BMI) according to BMl group and to feed intake condition during seasonal reproductive transitions ${ }^{1}$

\begin{tabular}{|c|c|c|c|}
\hline $\mathrm{HBMI}^{2}$ & LBMI & WOFIR & WFIR \\
\hline \multicolumn{4}{|c|}{ Transition into anovulatory season } \\
\hline $\begin{array}{l}11.2 \pm 0.44 \text { a } \\
\quad(n=6)\end{array}$ & $\begin{array}{c}8.1 \pm 0.36 b \\
(n=6)\end{array}$ & $\begin{array}{l}9.6 \pm 0.41 \\
\quad(n=6)\end{array}$ & $\begin{array}{l}9.7 \pm 0.41 \\
(n=6)\end{array}$ \\
\hline \multicolumn{4}{|c|}{ Transition into breeding season } \\
\hline $\begin{array}{l}12.3 \pm 0.46 \\
(n=6)\end{array}$ & $\begin{array}{l}8.6 \pm 0.46 b \\
(n=6)\end{array}$ & $\begin{array}{l}10.9 \pm 0.46 \\
(n=6)\end{array}$ & $\begin{array}{l}10.2 \pm 0.46 \\
\quad(n=6)\end{array}$ \\
\hline \multicolumn{4}{|c|}{1 Mean \pm standard error. } \\
\hline \multicolumn{4}{|c|}{$\begin{array}{l}2 \text { Groups with high (HBMI) or low (LBMI) body mass index and without (WOFIR) or with (WFIR) } \\
\text { temporal restriction on daily feed intake. }\end{array}$} \\
\hline \multicolumn{4}{|c|}{$\begin{array}{l}\text { ab Within factor, different superscript between columns indicates statistical difference }(P<0.01) \text {. Means } \\
\text { at the BMI } \times \mathrm{Fl} \text { interaction are not shown, } P>0.10 \text {. }\end{array}$} \\
\hline
\end{tabular}


subgrupos correspondientes no afectó su IMC (Cuadro 1).

Concentraciones séricas de LH en la transición a la época anovulatoria

Durante esta transición, la frecuencia de pulsos de LH sólo fue influenciada por el periodo de muestreo $(P<0.01)$ y por el nivel de índice de masa corporal $(P<0.05)$. La FPLH disminuyó de manera gradual conforme avanzó el año hacia la época anovulatoria $\left(2.08^{\mathrm{a}}, 1.41^{\mathrm{ab}}\right.$ y $0.41^{\mathrm{b}}$ pulsos $/ 6 \mathrm{~h}$, ee $=0.32$, para los PER 1,2 y 3 ). Por otro lado, el grupo de cabras con IMCA presentó una mayor FPLH que el grupo con IMCB, independientemente del periodo de muestreo (2.05 vs 0.55 pulsos/6 $\mathrm{h}$, ee $=0.26$ ).

La concentración media de LH fue influenciada por el periodo de muestreo $(P<0.01)$ y la interacción entre los factores IMC $\times$ CA $\times$ PER $(P<0.05)$. Al igual que la FPLH, la $\mathrm{CMLH}$ disminuyó a medida que avanzó el año hacia la época anovulatoria $\left(2.10^{\mathrm{a}}, 1.21^{\mathrm{b}}\right.$ y $0.51^{\mathrm{b}} \mathrm{ng} /$ $\mathrm{ml}$, ee $=0.21$, para los PER 1,2 y 3 ). En el caso de la interacción entre el IMC x CA $x$ and the sampling period (PER; sampling 1, 2 and 3 or sampling 4, 5 and 6) as the subplot effect, in a full factorial arrangement. Data of the LHF were transformed to square root of $Y+0.5$ for statistical analysis(21), but the untransformed values are presented in the results section.

\section{RESULTS}

Body mass index

In both transition periods, the BMI response variable was influenced by the effect of BMI group $(P<0.01)$, but not by the FI or the BMI $\mathrm{X}$ FI interaction $(P<0.10)$. The results indicate that the condition of temporary restriction on feed intake in the corresponding subgroups did not affect the BMI (Table 1).

Serum concentrations of $\mathrm{LH}$ in the transition to the anovulatory season

During this transition, LH pulse frequency was only influenced by the sampling period $(P<0.01)$ and by the level of body mass index $(P<0.05)$. The LHF decreased gradually as the year advanced towards the anovulatory season

Figura 2. Cambios en la concentración media de LH por efecto de la interacción entre el índice de masa corporal (BMI; alto HBMI, o bajo LBMI), el consumo diario de alimento (sin WOFIR, y con restricción WFIR) y el periodo de muestreo (PER)

Figure 2. Changes in mean LH concentration due to the interaction between body mass index (BMl; high HBMI or low LBMI), daily feed intake (Fl; without restriction WOFIR or with temporal restriction WFIR) and sampling period (PER)
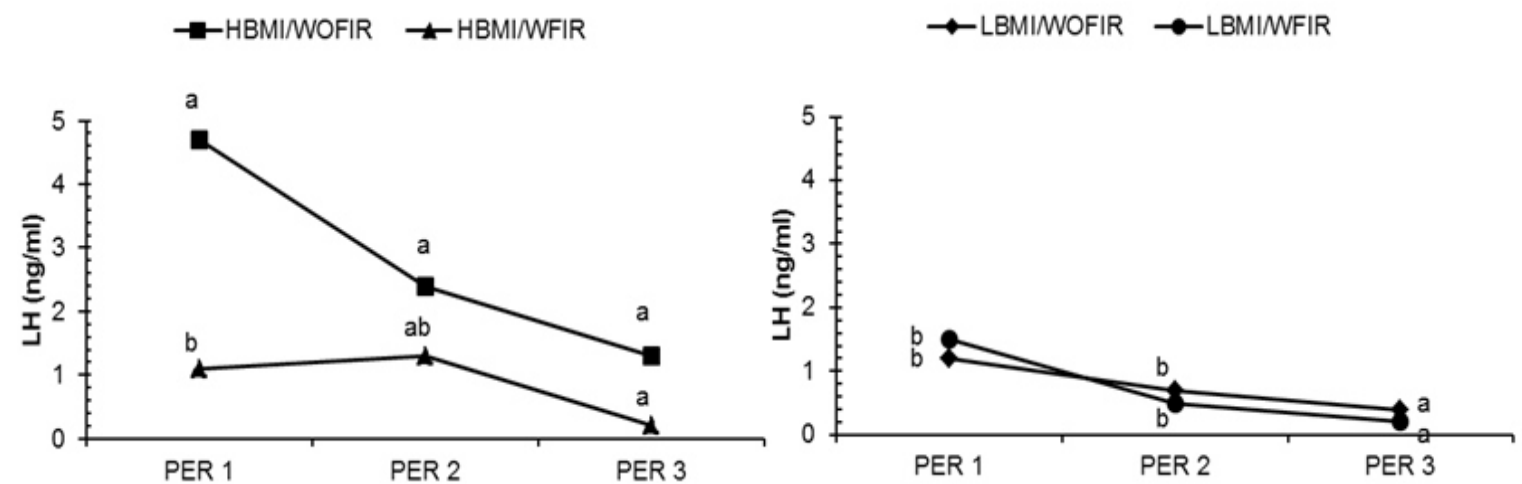

(PER 1, 2 and 3 = February/16, March/9 and March/30). ab Within PER, different script indicates statistical difference $(P<0.05$; se $=0.43)$. 
PER, se puede observar que en todos los grupos de tratamiento se presentó una disminución de la CMLH a medida que avanzó el año (Figura 2); sin embargo, el perfil de disminución fue diferente entre grupos, específicamente en el de IMCA/SRCA con respecto a los demás; las cabras con IMCA presentaron CMLH mayores que las de IMCB durante los periodos 1 y 2 cuando no fueron restringidas en CA (grupo IMCA/SRCA), pero cuando sí fueron restringidas (grupo IMCA/CRCA), se anuló esta diferencia, haciendo que su perfil de cambio fuera similar al de cabras con IMCB.

La concentración basal de LH fue influenciada por el periodo de muestreo $(P<0.01)$ y la interacción entre los factores IMC $\times$ CA $\times$ PER $(P<0.05)$. Asimismo, se observó una tendencia de efecto ocasionado por la interacción entre el CA $x$ PER $(P=0.07)$. La CBLH mostró una disminución conforme se avanzó a la época anovulatoria $\left(1.32^{\mathrm{a}}, 0.76^{\mathrm{b}}\right.$ y $0.35^{\mathrm{b}} \mathrm{ng} / \mathrm{ml}$, ee= 0.15 , para los PER 1,2 y 3 ).

En cuanto al efecto de la interacción IMC x CA $x$ PER (Figura 3), éste se manifestó de manera similar a lo observado con la CMLH; la restricción
(2.08, $1.41^{\mathrm{ab}}$ and $0.41^{\mathrm{b}}$ pulses $/ 6 \mathrm{~h}$, se $=$ 0.32, for PER 1, 2 and 3). On the other hand, the HBMI group presented a greater LHF than the LBMI group, regardless of the sampling period (2.05 vs 0.55 pulses $/ 6 \mathrm{~h}, \mathrm{se}=0.26$ ).

Mean LH concentration was influenced by the sampling period $(P<0.01)$ and the interaction between the BMI $\times$ FI $\times$ PER factors $(P<0.05)$. Similar to LHF, the LHM decreased as the year advanced towards the anovulatory season $\left(2.10^{\mathrm{a}}, 1.21^{\mathrm{b}}\right.$ and $0.51^{\mathrm{b}} \mathrm{ng} / \mathrm{ml}$, se $=0.21$, for PER 1, 2 and 3). In the case of the interaction between BMI x FI x PER, all treatment groups showed a decrease of the LHM as the year advanced (Figure 2); however, the profile of the decrease was different among groups, specifically of HBMI/WOFIR with respect to others; goats with HBMI presented higher LHM than LBMI goats during periods 1 and 2 when they were not restricted in FI (group HBMI/ WOFIR), but when they were restricted (group HBMI/WFIR), this difference was nullified having both, HBMI and LBMI goats, a similar profile.

Basal LH concentration was influenced by the sampling period $(P<0.01)$ and the interaction

Figura 3. Cambios en la concentración basal de LH por efecto de la interacción entre el índice de masa corporal (BMl; alto HBMI, o bajo LBMI), el consumo diario de alimento (sin WOFIR, y con restricción WFIR) y el periodo de muestreo (PER)

Figure 3. Changes in basal LH concentration due to the interaction between body mass index (BMl; high HBMI or low LBMI), daily feed intake (Fl; without restriction WOFIR or with temporal restriction WFIR) and sampling period (PER)
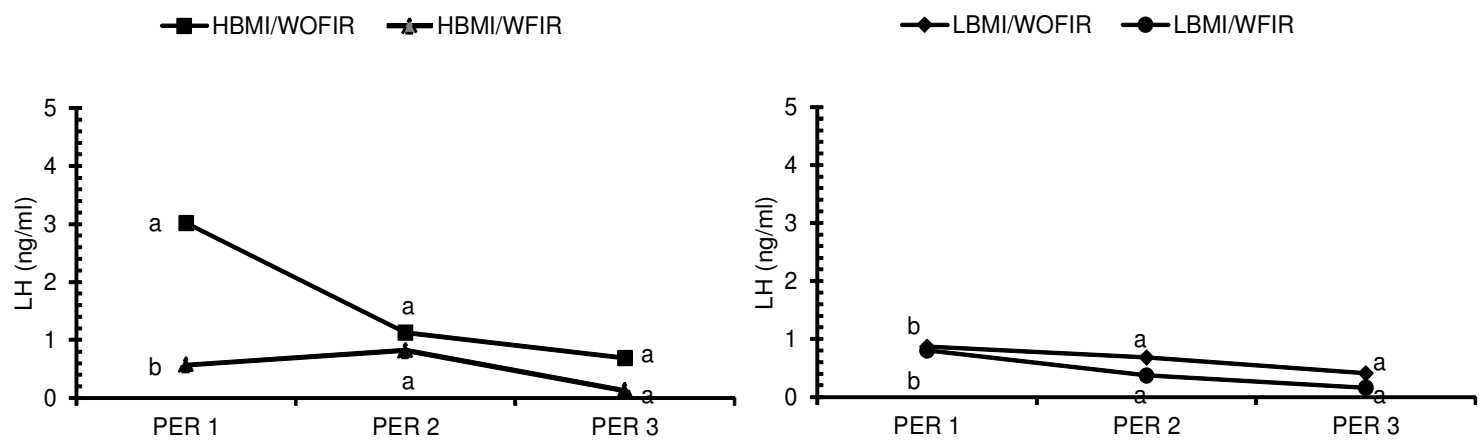

PER 1,2 and 3 = February/16, March/9 and March/30).

ab Within PER, different script indicates statistical difference $(P<0.05$; se $=0.27)$. 
en el CA anuló el efecto positivo del IMC alto, esto último reflejado en una mayor $\mathrm{CBLH}$ al inicio del periodo de transición comparado con cabras de IMCB. Por su parte, la tendencia de efecto por la interacción CA x PER implicó que aunque en las dos condiciones de $\mathrm{CA}$ se presentó una disminución gradual de la CBLH, la restricción nutricional provocó que los valores para esta variable fueran más bajos que en la condición no restringida, sobre todo al inicio de la etapa evaluada $\left(1.95^{\mathrm{a}}, 0.91^{\mathrm{b}}, 0.55^{\mathrm{bc}}\right.$ vs $0.68 \mathrm{bc}, 0.60 \mathrm{bc}, 0.15 \mathrm{c} \mathrm{ng} / \mathrm{ml}$, ee $=0.21$, para los grupos SRCA y CRCA durante los PER 1, 2 y 3 ).

Concentraciones séricas de LH en la transición a la época reproductiva

Para esta transición, la frecuencia de pulsos de LH fue influenciada por las condiciones de índice de masa corporal $(P<0.01)$ y de consumo de alimento $(P<0.01)$. No se encontraron diferencias $(P>0.10)$ por efecto del periodo de muestreo o de las interacciones entre factores principales para esta variable. El grupo de cabras con IMCA presentó mayor FPLH que el grupo con IMCB (3.22 vs 0.88 pulsos $/ 6 \mathrm{~h}$, ee $=0.21$ ). Por su parte, el grupo SRCA también mostró una mayor FPLH respecto al grupo CRCA (2.83 vs 1.27 pulsos $/ 6 \mathrm{~h}$, ee $=0.21$ ).

La concentración media de LH fue influenciada por el periodo de muestreo $(P<0.01)$ y el índice de masa corporal $(P<0.01)$ y además se observó una tendencia $(P=0.06)$ de efecto asociado al consumo diario de alimento. La CMLH se incrementó a medida que avanzó el año hacia el otoño $\left(1.01^{\mathrm{b}}, 1.58^{\mathrm{a}}\right.$ y $1.87^{\mathrm{a}} \mathrm{ng} /$ $\mathrm{ml}$, ee $=0.26$, para los PER 4,5 y 6 ). El grupo de cabras con IMCA presentó mayor CMLH que el grupo con IMCB, independientemente del periodo de muestreo $(2.10$ vs $0.87 \mathrm{ng} / \mathrm{ml}$, $\mathrm{ee}=0.10)$. En cuanto a la tendencia de efecto por consumo de alimento, el grupo de cabras SRCA presentó mayor CMLH que el grupo CRCA (1.89 vs $1.08 \mathrm{ng} / \mathrm{ml}$, ee= 0.10).

La concentración basal de LH fue influenciada por el periodo de muestreo $(P<0.01)$, el between the BMI $\times$ FI $\times$ PER factors $(P<0.05)$. There was also a trend of effect caused by the FI $x$ PER interaction $(P=0.07)$. The LHB showed a decrease as it progressed to the anovulatory season $\left(1.32^{\mathrm{a}}, 0.76^{\mathrm{b}}\right.$ and $0.35^{\mathrm{b}} \mathrm{ng} / \mathrm{ml}$, se $=0.15$, for PER 1, 2 and 3). As for the effect of the BMI $x$ FI $x$ PER interaction (Figure 3), this interaction influenced LHB in a similar way as it did with LHM; the restriction on the FI overturned the positive effect of the high BMI, the latter reflected in a higher LHB at the beginning of the transition period compared to goats of LBMI, but only in non-restricted animals. Moreover, the trend of effect of FI $x$ PER interaction implied that although in the two FI conditions the LHB diminished gradually, restricted goats had lower LHB values as compared to non-restricted goats, especially at the beginning of the evaluated stage (1.95a, $0.91 \mathrm{~b}, 0.55^{\mathrm{bc}}$ vs $0.68 \mathrm{bc}, 0.60^{\mathrm{bc}}, 0.15^{\mathrm{c}} \mathrm{ng} / \mathrm{ml}$, $\mathrm{se}=0.21$, for groups WOFIR and WFIR for PER $1,2,3)$.

Serum concentrations of $\mathrm{LH}$ in the transition to the reproductive season

For this transition, LH pulse frequency was influenced by the conditions of body mass index $(P<0.01)$ and feed intake $(P<0.01)$. No differences $(P>0.10)$ in LHF were observed due to sampling periods or related to the interactions among the evaluated factors. The goats in the HBMI group presented higher LHF than those in the LBMI group (3.22 vs 0.88 pulses $/ 6 \mathrm{~h}$, $\mathrm{se}=0.21)$. Moreover, WOFIR goats showed also a greater LHF as compared to WFIR goats ( 2.83 vs 1.27 pulses $/ 6 \mathrm{~h}, \mathrm{se}=0.21$ ).

Mean LH concentration was influenced by the sampling period $(P<0.01)$ and body mass index $(P<0.01)$, and in addition, there was a trend $(P=0.06)$ of effect associated with daily feed intake for this response variable. The LHM increased as year advanced to autumn $\left(1.01^{\mathrm{b}}\right.$, $1.58^{\mathrm{a}}$ and $1.87 \mathrm{a} \mathrm{ng} / \mathrm{ml}$, se $=0.26$, for PER 4, 5 and 6). The goats in the HBMI group presented higher LHM than those in the LBMI group, regardless of the sampling period ( 2.10 vs 0.87 
consumo de alimento $(P<0.05)$ y por la interacción entre el IMC $\times$ PER $(P<0.01)$. También se observó una tendencia de efecto por índice de masa corporal $(P=0.07)$. La CBLH incrementó a medida que avanzó el año hacia el otoño $\left(0.57 \mathrm{~b}, 0.98^{\mathrm{a}}\right.$ y $1.04^{\mathrm{a}} \mathrm{ng} / \mathrm{ml}$, ee= 0.06 , para los PER 4,5 y 6). El grupo de cabras SRCA presentó mayor CBLH que el grupo CRCA, independientemente del periodo de muestreo $(1.18$ vs $0.55 \mathrm{ng} / \mathrm{ml}$, ee= 0.10$)$. En la interacción IMC $x$ PER, se observó que en ambos grupos la CBLH aumentó a medida que el año avanzó hacia el otoño; sin embargo, el grupo de IMCA presentó valores estadísticamente superiores de CBLH dentro de los PER 5 y 6 comparado con el grupo de IMCB $\left(0.67 \mathrm{a}, 1.39 \mathrm{~b}, 1.41^{\mathrm{b}}\right.$ vs $0.47 \mathrm{a}, 0.57 \mathrm{a}$, $0.68^{\mathrm{a}} \mathrm{ng} / \mathrm{ml}$, ee $=0.09$, para los grupos IMCA y IMCB durante los PER 4, 5 y 6). En el caso de la tendencia de efecto por IMC, el grupo de cabras con IMCA presentó mayor CBLH que el grupo con IMCB (1.16 vs $0.57 \mathrm{ng} / \mathrm{ml}$, $\mathrm{ee}=0.05)$.

\section{DISCUSIÓN}

Los valores de IMC de los animales experimentales durante ambos periodos de transición (Cuadro 1), indican que sí se logró el paradigma experimental deseado: disociar el efecto de reservas corporales de energía, representadas por el IMC, del asociado al consumo diario de alimento (efecto de grupo de IMC pero no de grupo de CA o de la interacción IMC x CA).

En el caso de $\mathrm{LH}$, cabe mencionar que las concentraciones séricas de la hormona se consideran un buen indicador de su patrón de secreción a nivel hipofisiario(5). En ese sentido, los resultados indican que en cabras de estacionalidad moderada, la secreción de LH (y por inferencia de $\mathrm{GnRH}$ ) es modulada por el estado nutricional de los animales en ambos periodos de transición. Asimismo, sustentan parcialmente la hipótesis planteada, ya que la $\mathrm{ng} / \mathrm{ml}$, se $=0.10)$. The trend of effect of $\mathrm{FI}$ implied that the WOFIR goats group presented higher LHM than the WFIR group (1.89 vs 1.08 $\mathrm{ng} / \mathrm{ml}$, se= 0.10).

Basal LH concentration was influenced by the sampling period $(P<0.01)$, feed intake $(P<0.05)$ and by the BMI $x$ PER interaction $(P<0.01)$. A trend of effect was also observed for BMI $(P=0.07)$. The LHB increased as year advanced to autumn $\left(0.57 \mathrm{~b}, 0.98^{\mathrm{a}}\right.$ and $1.04 \mathrm{a} \mathrm{ng} / \mathrm{ml}$, se $=$ 0.06 for PER 4, 5 and 6 ). The WOFIR group presented higher LHB than the WFIR group, regardless of the sampling period ( 1.18 vs 0.55 $\mathrm{ng} / \mathrm{ml}$, se $=0.10$ ). For BMI $\times$ PER interaction, it was observed that the LHB increased as the year advanced toward the autumn regardless of BMI level, however, the HBMI group presented statistically higher values of LHB within the PER 5 and 6 as compared to the LBMI group $\left(0.67 \mathrm{a}, 1.39^{\mathrm{b}}, 1.41^{\mathrm{b}}\right.$ vs $0.47 \mathrm{a}, 0.57^{\mathrm{a}}$, $0.68^{\mathrm{a}} \mathrm{ng} / \mathrm{ml}$, se $=0.09$ for HBMI and LBMI during PER 4, 5 and 6). In the case of the BMI trend effect, the goats in the HBMI group presented higher LHB than those in the LBMI group (1.16 vs $0.57 \mathrm{ng} / \mathrm{ml}$, se= 0.05).

\section{DISCUSSION}

The BMI values of the experimental animals during both transition periods (Table 1 ) indicate that the expected experimental paradigm was effectively achieved: dissociate the effect of body energy reserves, represented by the BMI, from the effect of daily feed intake (effect of BMI level but not of FI condition or of the BMI x FI interaction).

Regarding $\mathrm{LH}$, it is worth mentioning that serum hormone concentrations are considered a good indicator of its pituitary secretion pattern(5). In that sense, the results indicate that in goats of moderate seasonality, LH secretion (and by inference, of $\mathrm{GnRH}$ ) is modulated by the nutritional status of animals in both transition periods. It also partially supports the experimental hypothesis, since the LH secretion during both transition periods was modulated 
secreción de LH durante ambos periodos de transición fue modulada tanto por la condición de reservas corporales de energía (IMC), como por su ingreso a través del consumo diario de alimento. Sin embargo, durante la transición hacia la época anovulatoria, se observó que el efecto regulador de la restricción alimenticia se impuso al efecto de las reservas corporales de energía (Figuras 2, 3).

En cuanto al efecto del periodo de muestreo, la secreción de LH disminuyó durante la transición hacia la época anovulatoria y se incrementó durante la transición hacia la época reproductiva. Resultados similares han sido observados en otros estudios realizados en cabras de razas consideradas de estacionalidad reproductiva moderada(22,23). En estos animales, se ha determinado que durante las épocas de transición reproductiva, la secreción de LH es regulada por cambios en la sensibilidad hipotalámica a la retroalimentación negativa de los estrógenos. También se ha indicado que las variaciones estacionales en la secreción de $\mathrm{LH}$, dependen de un ritmo endógeno reproductivo anual, el cual es sincronizado por la secuencia de cambios en duración del fotoperiodo a través del año $(4,24)$.

Respecto al efecto del estado nutricional durante los periodos de transición reproductiva, se ha observado que una baja condición corporal en ovejas $(25,26,27)$, o un periodo prolongado de subalimentación en cabras de baja estacionalidad reproductiva(23), afectan la secreción de LH. Sin embargo, no existen estudios que hayan descrito una reducción en las concentraciones séricas de esta hormona, debido a restricciones temporales en el consumo de alimento, incluso en cabras con altas reservas corporales de energía. La generalidad de las publicaciones en rumiantes domésticos, indica que la secreción de LH sólo es afectada en circunstancias de restricción alimenticia prolongada $(7,28,29)$, o sólo en animales con bajas reservas corporales de energía después de un ayuno relativamente prolongado(15). Los resultados del presente trabajo sugieren que en cabras de estacionalidad moderada, el by the condition of the body energy reserves (BMI), as well as by the energy income associated with the daily feed intake. However, during the transition to the anovulatory season, the regulating effect of feed restriction was imposed over the effect of body energy reserves (Figures 2, 3).

Regarding the effect of the sampling period, $\mathrm{LH}$ secretion diminished during the transition to the anovulatory season and increased during the transition to the reproductive season. Similar results have been observed in goat breeds considered as of moderate reproductive seasonality $(22,23)$. In these animals, it has been determined that during times of reproductive transition, LH secretion is regulated by changes in hypothalamic sensitivity to the negative feedback of estrogens. It has also been suggested, that the seasonal variations in the LH secretion depend on an annual reproductive endogenous rhythm, which is synchronized by the sequence of changes in photoperiod duration throughout the year $(4,24)$.

About the effect of nutrition during periods of reproductive transition, there has been observed that a low body condition in ewes $(25,26,27)$, or a prolonged period of under-nourishment in low reproductive seasonality goats(23), affect LH secretion. However, there are not studies describing a reduction in serum concentrations of this hormone, due to temporary restrictions on the feed intake, even in goats with high body energy reserves. The majority of publications in domestic ruminants, indicates that LH secretion is affected only in circumstances of prolonged feed restriction $(7,28,29)$, or only in animals with low body energy reserves after a relatively prolonged fasting(15). The results of this study suggest that in goats of moderate seasonality, the regulatory system of the $\mathrm{GnRH} /$ LH secretion is capable of dissociate and respond differentially to signals relating to the feed intake or body energy reserves, particularly during periods of transitional reproduction. 
sistema regulador de la secreción de GnRH/LH es capaz de disociar y responder diferenciadamente a señales relacionadas con el consumo de alimento o con las reservas corporales de energía, particularmente durante los periodos de transición reproductiva.

La mayor respuesta del sistema neuronal regulador de la secreción de $\mathrm{GnRH} / \mathrm{LH}$ hacia las señales relacionadas con el consumo de alimento, podría indicar un mecanismo de adaptación de las cabras criollas a las condiciones de escasez de forraje a las que comúnmente deben hacer frente. En México, la mayoría de las cabras son mantenidas en agostaderos en donde la disponibilidad de alimento es fluctuante a través del año(30). En este sentido, se ha propuesto que la habilidad del eje hipotálamo-hipófisis para responder rápidamente a los cambios en la alimentación (incremento o deficiencia), puede ser una estrategia para la sobrevivencia y perpetuación de las especies(31). Como ejemplo, en regiones donde la disponibilidad de alimento es muy fluctuante, existen razas de ovejas que han desarrollado una estrategia reproductiva de tipo oportunista. Esta estrategia, implica que la actividad ovulatoria es inducida rápidamente por incrementos en el consumo de alimento aún durante la época de anestro, lo cual demuestra que el efecto regulador de la nutrición sobre la actividad reproductiva se impone al del fotoperiodo(32). De manera similar, las señales asociadas al consumo de alimento podrían reflejar la condición energética actualizada de las cabras criollas, y convertirse en el componente nutricional de mayor importancia para el sistema neuronal regulador de la secreción de $\mathrm{GnRH} / \mathrm{LH}$ durante los periodos de transición reproductiva. Sin embargo, a diferencia de la estrategia oportunista de las ovejas, en las cabras el fotoperiodo sigue manteniéndose como el sincronizador primario de la actividad estacional reproductiva, y la condición nutricional actúa más bien como un modulador secundario.
The greater response of the neuronal regulator system of $\mathrm{GnRH} / \mathrm{LH}$ secretion to the feed intakerelated signals, could indicate an adaptive mechanism to the conditions of scarcity of fodder in Creole goats, situation to which they commonly must cope. In Mexico, the majority of goats are kept in rangelands where feed availability is fluctuating throughout the year(30). In this regard, it is proposed that the ability of the hypothalamus to respond quickly to changes in feed intake (increase or decrease), could be an strategy for the survival and perpetuation of the species(31). As an example, in regions where feed availability is very fluctuating, there are breeds of sheep that have developed a reproductive strategy of opportunistic type. This strategy implies that ovulatory activity is induced rapidly by an increase in feed intake even during the anestrus season, which shows that the regulatory effect of nutrition on the reproductive activity is imposed over the effect of photoperiod(32). Similarly, signals associated with the feed intake could depict the updated energy condition of the Creole goats, and become the nutritional component of greater importance for the neuronal regulator system of $\mathrm{GnRH} / \mathrm{LH}$ secretion during reproductive transition periods. However, unlike the opportunist strategy of sheep, in goats, the photoperiod continues staying as the primary synchronizer of seasonal reproductive activity, and the nutritional condition acts as a secondary modulator.

This is supported by the results of another study conducted in parallel (same genotype, location, treatments and handling characteristics), in which ovulatory activity during periods of reproductive transition was affected by the temporary restriction in feed intake and not by the status of body energy reserves( 3 ). However, if the LH secretion is also affected by a low level of body energy reserves as occurred in the present study, the question is: why this effect was not reflected in the ovulatory response evaluated in the previously mentioned work? This situation 
Lo anterior es apoyado por los resultados de otro estudio realizado de manera paralela (mismo genotipo, ubicación, tratamientos y características de manejo), en el cual la actividad ovulatoria durante los periodos de transición reproductiva fue afectada por la restricción temporal del consumo de alimento y no por el estado de reservas corporales de energía(3). Sin embargo, si la secreción de LH también es afectada por un nivel bajo de reservas corporales de energía como ocurrió en el presente estudio, la pregunta es: ¿Por qué este efecto no se vio reflejado en la actividad ovulatoria evaluada en el trabajo previamente mencionado? Esta situación sugiere la posibilidad de que durante los periodos de transición reproductiva, el efecto del estado nutricional sobre la actividad ovulatoria también involucre a una regulación directa a nivel ovárico. Asimismo, que cada componente del estado energético pueda generar señales con efecto diferencial en la regulación de la actividad ovárica. Esa regulación podría involucrar una vía independiente de $\mathrm{LH}$ con efecto propio o que potencialice el efecto de la gonadotropina. Una situación similar se presenta en machos ovinos Merino, en los cuales el ciclo de crecimiento testicular está asociado a cambios nutricionales que no producen cambios en la secreción de gonadotropinas(32).

Por otra parte, se ha demostrado en pequeños rumiantes que glucosa, insulina, IGF-I y leptina son mediadores importantes para el efecto del estado energético sobre la actividad ovulatoria, con efectos ováricos directos e indirectos a través de la regulación de la secreción de $\mathrm{GnRH} /$ $\mathrm{LH}(33,34,35)$. En ese sentido, se ha observado que las concentraciones circulantes de estos señalizadores metabólicos se ve disminuida en animales con bajas reservas de energía, así como en aquellos sometidos a restricción en el consumo de alimento(11,25,36). Existe por lo tanto la posibilidad de que la disminución en secreción de LH observada en las cabras con restricción alimenticia o con bajas reservas de energía, pudiera haber involucrado una disminución en las concentraciones de los suggests that during reproductive transition periods, nutritional status might exert a direct regulation of ovulatory activity at the ovary level. In addition to it, each component of the energy status might be able to generate signals with differential effect in the regulation of ovarian activity. Such regulation could involve a proper via independent of $\mathrm{LH}$ or related to an increased sensitivity to the gonadotropin and an amplification of its effect. A similar situation occurs in males Merino sheep, in which testicular growth cycle is associated with nutritional changes that do not produce alterations in the gonadotropins secretion(32).

On the other hand, it has been shown in small ruminants that leptin, glucose, insulin and IGF-I are important mediators for the effect of the energy status on ovulatory activity, with direct ovarian effects and indirect effects mediated through the regulation of $\mathrm{GnRH} / \mathrm{LH}$ secretion $(33,34,35)$. In this regard, it has been observed that the circulating concentrations of the mentioned metabolic signals is decreased in animals with low energy reserves, as well as in those subjected to feed intake restriction $(11,25,36)$. There is therefore the possibility that the decrease in LH secretion observed in goats with feed restriction or low body energy reserves, could have involved a decrease in the concentrations of the above metabolic signals, although this was not demonstrated in the present study.

\section{CONCLUSIONS AND IMPLICATIONS}

During periods of reproductive transition, $\mathrm{LH}$ secretion is modulated both, by body energy reserves and daily feed intake in goats that show moderate reproductive seasonality. However, during the transition to the anovulatory season, the importance of the temporal restriction on feed intake effect increases, in such a way that it is capable of reducing $\mathrm{LH}$ secretion even in goats with good body energy reserves. 
señalizadores mencionados, aunque esto no se demostró en el presente estudio.

\section{CONCLUSIONES E IMPLICACIONES}

Durante los periodos de transición reproductiva, la secreción de LH es modulada tanto por las reservas corporales de energía como por el consumo diario de alimento en cabras de estacionalidad reproductiva moderada. Sin embargo, durante la transición a la época anovulatoria, aumenta la importancia del efecto de restricción temporal en el consumo de alimento, ya que es capaz de disminuir la secreción de LH aún en cabras con buenas reservas corporales de energía.

\section{AGRADECIMIENTOS}

Los autores agradecen al INIFAP por el financiamiento otorgado (Proyecto 1243491519) y las facilidades en la utilización de sus instalaciones para realizar la presente investigación.

\section{LITERATURA CITADA}

1. Zarazaga LA, Guzmán JL, Domínguez C, Pérez MC, Prieto R. Effect of plane of nutrition on seasonality of reproduction in Spanish Payoya goats. Anim Reprod Sci 2005;87(3-4):253257.

2. De Santiago-Miramontes MA, Malpaux B, Delgadillo JA. Body condition is associated with a shorter breeding season and reduced ovulation rate in subtropical goats. Anim Reprod Sci 2009;(114):175-182.

3. Estrada $\mathrm{CE}$, Vera $\mathrm{AHR}$, Urrutia MJ, Villagómez-Amezcua $\mathrm{ME}$, Jiménez SH, Mejía G, Rivera LMT, Gámez VHG. Nutritional status influences reproductive seasonality in Creole goats: 1. Ovarian activity during seasonal reproductive transitions. Anim Rep Sci 2009;16(3):282-290.

4. Chemineau P, Guillaume D, Migaud M, Thiery JC, PellicerRubio MT, Malpaux B. Seasonality of reproduction in mammals: intimate regulatory mechanisms and practical implications. Reprod Dom Anim 2008;43(Suppl 2):40-47.

5. Padmanabhan $\mathrm{V}$, McNeilly AS. Is there an FSH-releasing factor? Reproduction 2001;(121):21-30.

6. Lehman MN, Goodman RL, Karsch FJ, Jackson GL, Berriman SJ, Jansen HT. The GnRH system of seasonal breeders: Anatomy and Plasticity. Brain Res Bull 1997;44(4):445-457.

\section{ACKNOWLEDGMENTS}

The authors thank INIFAP (project 1243491519) for its support with the funding and facilities required to carry out this research.

End of english version

7. Imakawa $K$, Day ML, Garcia-Winder M, Zelesky DD, Kittok $\mathrm{RJ}$, Schanbacher BD, Kinder JE. Endocrine changes during restoration of estrous cycles following induction of anestrus by restricted nutrient intake in beef heifers. J Anim Sci 1986; (63):565-571.

8. Beckett JL, Sakurai H, Famula TR, Adams TE. Negative Feedback potency of estradiol is increased in orchidectomized sheep during chronic nutrient restriction. Biol Reprod 1997;(57):408-414.

9. Goodman RL, Maltby MJ, Millar RP, Hileman SM, Nestor CC, Whited B, Tseng AS, Coolen LM, Lehman MN. Evidence that dopamine acts via kisspeptin to hold $\mathrm{GnRH}$ pulse frequency in check in anestrous ewes. Endocrinology 2012;153:59185927.

10. Meza-Herrera CA, Hallford DM, Ortiz JA, Cuevas RA, Sánchez $\mathrm{JM}$, Salinas $\mathrm{H}$, et al. Body condition and protein supplementation positively affect periovulatory ovarian activity by non LH-mediated pathways in goats. Anim Reprod Sci 2008;(106):412-420.

11. IGPBRIA, International Guiding Principles for Biomedical Research Involving Animals. 2012. http://www.cioms.ch/ index.php/12-newsflash/227-cioms-and-iclas-release-thenew-international-guiding-principles-for-biomedical-researchinvolving-animals.

12. Archer ZA, Rhind SM, Findlay PA, Kyle CE, Thomas L, Marie $M$, Adam CL. Contrasting effects of different levels of food intake and adiposity on LH secretion and hypothalamic gene expression in sheep. J Endocrinol 2002;(175):383-393.

13. Mora O, Vera AH, Shimada A. Mecanismos celulares y endocrinos afectados por la subnutrición en pequeños rumiantes. Cienc Vet 2007;(10):107-135.

14. Schneider JE. Energy balance and reproduction. Physiol Behav 2004;(81):289-17.

15. Tanaka T, Akaboshi N, Inoue $\mathrm{Y}$, Kamomae $\mathrm{H}$, Kaneda $\mathrm{Y}$. Fasting-induced suppression of pulsatile luteinizing hormone secretion is related to body energy status in ovariectomized goats. Anim Reprod Sci 2002;(72):185-196.

16. Medan SM, Watanabe G, Sasaki K, Sharawy S, Groome PN, Taya K. Ovarian dynamics and their associations with peripheral concentrations of gonadotropins, ovarian steroids and Inhibin during the estrous cycle in goats. Biol Reprod 2003;(69):57-63.

17. Vilar-Martínez $H$, Vera-Ávila HR, González-Padilla E, LópezOrdaz R, Domínguez-Araujo G, Jiménez-Severiano H, MejíaGuadarrama C. Comparisson of different in vivo estimators of body fat and muscle content in adult creole goats. Trop Subtrop Agroecosystems 2009;(11):95-97. 
18. NRC. National Research Council. Nutrient requirements of domestic animals. Nutrient requirements of goats. Angora, dairy, and meat goats in temperate and tropical countries. Washington DC, USA: National Academy Press; 1981.

19. Arreguín AJA, Villa GA, Montaño BM, Villagómez AME, Román PH, Cárdenas LM. Interacción de la naloxona con la progesterona y el estradiol, durante el anestro posparto en las vacas cebú. Tec Pecu Mex 1995;33(2):53-65.

20. Merriam RG, Watcher KW. Algorithms for the study of episodic hormone secretion. Amer J Physiol 1982;243(Endocrinol Metab 6):E310-E318.

21. Little MT, Hills FJ. Métodos estadísticos para investigación en la agricultura. Sexta reimpresión. México: Trillas; 1976.

22. Duarte G, Flores JA, Malpaux B, Delgadillo JA. Reproductive seasonality in female goats adapted to a subtropical environment persists independently of food availability. Domest Anim Endocrinol 2008;(35):362-370.

23. Zarazaga LA, Celi I, Guzmán JL, Malpaux B. 2011. The response of luteinizing hormone secretion to photoperiod is modified by the level of nutrition in female Mediterranean goats. Anim Rep Sci 2001;(126):83-90.

24. Legan SJ, Karsch FJ. Importance of retinal photoreceptors to the photoperiodic control of seasonal breeding in the ewe. Biol Reprod 1983;(29):316-325.

25. Henry BA, Goding JW, Tilbrook AJ, Dunshea FR, Blache D, Clarke IJ. Leptin-mediated effects of undernutrition or fasting on luteinizing hormone and growth hormone secretion in ovariectomized ewes depend on the duration of metabolic perturbation. J Neuroendocrinol 2004;(16):244-255.

26. Rhind SM, McMillen S, McKelvey WAC. Effects of level of food intake and body condition on the sensitivity of the hypothalamus and pituitary to ovarian-steroid feedback in ovariectomized ewes. Anim Prod 1991;(52):115-125.

27. Snyder JL, Clapper JA, Roberts AJ, Sanson DW, Hamernik $\mathrm{DL}$, Moss GE. Insulin-like growth factor-I, insulin-like growth factor-binding proteins, and gonadotropins in the hypothalamic-pituitary axis and serum of nutrient-restricted ewes. Biol Reprod 1999;(61):219-224.

28. Chilliard Y, Bocquier F, Doreau M. Digestive and metabolic adaptations of ruminants to undernutrition and consequences on reproduction. Reprod Nutr Dev 1998;(38):131-152.

29. Tanaka T, Fujiwara KI, Kim S, Kamomae H, Kaneda H. Ovarian and hormonal responses to a progesterona-releasing controlled internal drug releasing treatment in dietaryrestricted goats. Anim Reprod Sci 2004;(84):135-146.

30. Ramirez RG, Loyo A, Mora R, Sanchez EM, Chaire A. Forage intake and nutrition of range goats in a shrubland in northeastern México. J Anim Sci 1991;(69):879-885.

31. Cameron JL. 1996. Regulation of reproductive hormone secretion in primates by short-term changes in nutrition. Rev Reprod 1996;(1):117-126.

32. Martin GB, Hötzel MJ, Blache D, Walkden-Brown SW, Blackberry MA, Boukhliq RC. Determinants of the annual pattern of reproduction in mature male merino and suffolk sheep: modification of responses to photoperiod by an annual cycle in food supply. Reprod Fertil Dev 2002;14(34):165-75.

33. Blache D, Zhang S, Martin GB. Dynamic and integrative aspects of the regulation of reproduction by metabolic status in male sheep. Reprod Nutr Dev 2006;(46):279-390.

34. Muñoz-Gutiérrez M, Findlay PA, Adam CL, Wax G, Campbell $B K$, Kendall NR, et al. The ovarian expression of mRNAs for aromatase, IGF-I receptor, IGF-binding protein-2, -4 and 5 , leptin and leptin receptor in cycling ewes after three days of leptin infusion. Reproduction 2005;130(5):869-881.

35. Scaramuzzi RJ, Campbell BK, Downing JA, Kendall NR, Khalid $M$, Muñoz-Gutierrez $M$, Somchit A. A review of the effects of supplementary nutrition in the ewe on the concentrations of reproductive and metabolic hormones and the mechanisms that regulate folliculogenesis and ovulation rate. Reprod Nutr Dev 2006;(46):339-354.

36. Marie M, Findlay PA, Thomas L, Adam CL. Daily patterns of plasma leptin in sheep: effects of photoperiod and food intake. J Endocrinol 2001;(170):277-286. 